\title{
Sometimes It's the Place: The Anabaptist Kingdom Revisited
}

\author{
HENRY SUDERMAN
}

University of Alberta

Interpretations of the Anabaptist Kingdom of Münster (23 February 1534 - 24 June 1535) and the actions of its primary protagonists have tended to be judgmental and dismissive, with little attention given to Münster Anabaptists' self-descriptions. Studies tend to focus on the wildly imaginative components of the Anabaptist Kingdom as evidence and means for its dismissal. A spatial interpretation of the Anabaptist Kingdom, in which spatial categories are substituted for more conventional social and political categories, holds at least four benefits: it offers a more direct and focused access point into the study of Anabaptist action; it more accurately reflects the concerns of lay Anabaptists and civil authorities; it proposes unparalleled precision in analysis; and it is a particularly suitable analytic for explaining certain forms of cultural contestation and resistance. It is through the introduction of a spatial methodology, in which the Anabaptist Kingdom is interpreted as a deliberately designed and carefully staged social theatre, focused on the representation of power, that the hitherto inexplicable becomes understandable.

Les études sur le royaume anabaptiste de Münster (23 février 1524-24 juin 1535) et sur les actions de ses principaux personnages semblent tendre aux jugements rapides et au mépris, sans accorder beaucoup d'attention aux descriptions que les anabaptistes de Münster donnent d'eux-mêmes. En effet, ces études ont tendance à se concentrer davantage sur le contenu de certaines fantaisies farfelues à l'égard du royaume anabaptiste afin de justifier leur mépris. Il y a plusieurs avantages à leur préférer une interprétation de l'espace du royaume anabaptiste qui remplace les catégories sociales et politiques plus conventionnelles par des categories spatiales. Cette démarche offre une porte d'entrée plus directe et mieux ciblée pour l'étude de l'action anabaptiste. Elle donne aussi un meilleur point de vue sur les préoccupations des anabaptistes laïcs et des autorités civiles. Enfin, elle permet une plus grande précision d'analyse et s'avère bien plus adaptée à expliquer certaines formes de contestations et de résistances culturelles. C'est décidément en adoptant une méthodologie spatiale, dans laquelle le royaume anabaptiste est interprété comme un théâtre social délibérément et minutieusement conçu, concentré sur une représentation des pouvoirs, que l'incompréhensible devient finalement compréhensible.

\section{ristotle noted that "an extraordinary importance attaches to place," and A that places exercise "influence on things." Places are not simple sites for human action, functioning as static backdrops into which thought or}

1. W. D. Ross, Aristotle's Physics: A Revised Text with Introduction and Commentary (Oxford: Clarendon Press: 1936), 370-71. 
action are inserted, as is often assumed in Anabaptist historiography. Places are intimately associated with the construction and maintenance of power relations, exercising agency in their formation, which provides them with their specificity and power. ${ }^{2}$ The places to which one did or did not go were decisive political acts in the early modern period. Culturally established spatial practices were not apolitical or value-neutral, as early Anabaptists demonstrated. Spatial practices were a form of political engagement that engendered social structure, constructing narratives of meaning through which community was imagined and maintained. Consequently, it was through alternative spatial practices that established social structure could be challenged and definitions of community could be contested. Because places affect humans determinatively, shaping their identities, attitudes, behaviours, thinking, and social relations, place emerges as an exceptionally vibrant and unparalleled category for cultural analysis.

Yet, little attention has been given to spatial considerations in Anabaptist historiography. Too often, scholarship has focused on discursive representations and not on the way in which myth, for example, remains fully dependent upon devices such as spatial boundaries. Within the historical record, medieval churches appear as much more than sites for liturgical practice regardless of the importance such activity may have held for some people. Medieval taxonomies of heaven and earth were critical to the construction and reception of Christian sacred space, but it was spatially defined and hierarchically arranged power relations of appropriation and dispossession, domination and subordination, and exclusion and inclusion that most accurately defined their operation. ${ }^{3}$ Researchers cannot simply retain a theological focus and accept so-called "objective" spatial representations that ignore individual subjective constructions and the effects of a particular place, or type of place, on a given subject. Medieval churches and the power they exercised cannot be adequately understood through appeal to the myths with which they were associated. Their analysis is dependent upon the investigation of the spatially specific social practices and political conventions churches fostered and maintained, and upon an examination of the identities

2. Keith H. Basso, "Wisdom Sits in Places: Notes on an Apache Landscape," in Senses of Place, ed. Steven Feld and Keith H. Basso (Santa Fe: School of American Research Press, 1996), 56-57.

3. David Chidester and Edward T. Linenthal, American Sacred Space (Bloomington and Indianapolis: Indiana University Press, 1995), 15. 
they generated and reinforced. ${ }^{4}$ Within such an analytic, late medieval churches emerge as socially significant, politically indispensable, physically imposing, and culturally determinate places. They function as primary instruments for forcibly perpetuating a particular cosmology and structuring a specific sort of community. Churches affected memory, shaped identity, established power relations, and maintained other significant facets of domestic and communal medieval life, to which sixteenth-century Anabaptists emerged as an allergic reaction. Moreover, with very few exceptions, Anabaptists did not appear as thinkers or theologians in the sixteenth century, but as a direct and decided hostile reaction to the role churches played and the power they exercised in the construction and maintenance of medieval society.

The Anabaptist Kingdom of Münster (23 February 1534 - 24 June 1535) remains an exceptional event in Anabaptist history, but it was not antithetical to early sixteenth-century Anabaptist values and priorities. The Anabaptist Kingdom functioned as a graphic representation of the dominant culture, its hierarchical structure, and its exercise of power through violence. It was designed as an opportunity for imagining alternative socio-political models for the exercise of power. It was through the Anabaptist Kingdom that limited opportunity emerged for imagining freedom from the dominant discourse of power and the exercise of violence in which Anabaptists were enmeshed. It was through the development and effective exploitation of the plenitude of aesthetic space-which retains the ability to decisively transcend coercion and dominance through its suspension of "reality", even if its effects and transcendence are generally only temporary-that Münsterite ${ }^{5}$ Anabaptists realized some of their socio-political goals.

My argument is not so much an attempt to displace earlier research agendas as it is an effort to avoid the dismissiveness to which the Anabaptist

4. Glenn Bowman, "Nationalizing the Sacred: Shrines and Shifting Identities in the Israeli-Occupied Territories," Man, n.s., 28.3 (1993): 432.

5. The term "Münsterite" is used throughout this project as a descriptor for persons living in the city of Münster from 23 February 1534 to 24 June 1535, irrespective of the degree to which they did or did not subscribe to and/or support the various programs, initiatives, innovations, and actions associated with the Anabaptist Kingdom of Münster. The term is a convenient and reasonably suitable descriptor for the inhabitants of Münster during this period of its history when it is divorced from polemical considerations or negative associations. At times it will be necessary to distinguish individuals and groups within this homogenizing term. 
Kingdom is generally subjected. Through a serious look at Münsterite selfdescriptions and the employment of an analytic that privileges places and not theology, Anabaptist Münster emerges as social theatre. "Theatre" shares the same root as the word "theory" (theoria), and refers to the matter of looking at, showing, or beholding attentively, ${ }^{6}$ making the examination of Anabaptist theatre at Münster an appropriately theoretical enterprise. The Anabaptist Kingdom then emerges as an early positive attempt to move beyond criticism of the dominant society to imagining several radical socio-political structures. This short-lived, peculiar, and wildly imaginative Anabaptist socio-spatial construction was vehemently rejected and violently suppressed by sixteenthcentury authorities even though it was difficult and quite costly to do so.

Unfortunately, historians often approach the Anabaptist Kingdom with a hostile or dismissive attitude, interpreting this brief but colourful experiment as a "debacle" or "catastrophe," with its principal actors frequently judged as "fanatical." Church historians are generally scandalized by events as they unfolded in Anabaptist Münster, and are frequently unable to make sense of this episode in early modern history, and simply react negatively. The self-descriptions of Münsterites, and all that they claimed the Anabaptist Kingdom sought to do, and all it sought to represent, are systematically ignored or rejected in the literature as deviant and aberrant. ${ }^{10}$ The substitution of spatial categories for more conventional social, political, and moral categories holds at least four benefits: it offers a more direct and focused access point into the study of Anabaptist action; it more accurately reflects the concerns of lay Anabaptists and civil authorities;

6. David Michael Levin, The Opening of Vision: Nihilism and the Premodern Situation (New York: Routledge, 1987), 99f. Cited in Martin Jay, Downcast Eyes: The Denigration of Vision in TwentiethCentury French Thought (Berkeley: University of California Press, 1994), 23.

7. R. Po-chia Hsia, Society and Religion in Münster, 1535-1618 (New Haven and London: Yale University Press, 1984), 54. See also R. Po-chia Hsia, "Münster and the Anabaptists", in The German People and the Reformation, ed. R. Po-chia Hsia (Ithaca: Cornell University Press, 1988).

8. Sigrun Haude, In the Shadow of "Savage Wolves": Anabaptist Münster and the German Reformation during the 1530s (Boston: Humanities Press, 2000), 5.

9. Cornelius J. Dyck and Harold S. Bender, Mennonite Encyclopedia: A Comprehensive Reference Work on the Anabaptist-Mennonite Movement, 5 vols. (Hillsboro, KS: Mennonite Brethren Publishing House, 1955-90), 3:778.

10. Anthony Arthur, The Tailor-King: The Rise and Fall of the Anabaptist Kingdom of Münster (New York: St. Martin's Press, 1999), 1. 
it proposes unparalleled precision in analysis; and it is a particularly suitable analytic for explaining certain forms of cultural contestation and resistance.

\section{Münsterite theatre: context and construction}

Few documents produced by Münsterite Anabaptists have survived. ${ }^{11}$ Heinrich Gresbeck's chronicle, Berichte der Augenzeugen über das Münsterische Wiedertäuferreich (An eyewitness report concerning the Anabaptist Kingdom of Münster), ${ }^{12}$ is an exceptional record in that, although it is openly hostile to the Anabaptist Kingdom and was written after the events it describes had concluded, it is an eye-witness report that provides the reader with a detailed chronological record of events. It is the only first-hand account of how life was lived in the Anabaptist Kingdom and how events unfolded within the city. Like Gresbeck's chronicle, Hermann von Kerssenbrock's Anabaptistici Furoris Monasterium Inclitam Westphaliae Metropolim Evertentis Historica Narratio (Narrative history of the ruin of the Anabaptist madness in the renowned Westphalian metropolis of Münster) ${ }^{13}$ and Bernhard Rothmann's Restitution (Restoration), Bericht von der Wrake (Report on vengeance), and Van den Rike Christi (On Christ's kingdom) encourage a spatially-focused interpretation of the Anabaptist Kingdom of Münster. Each of these texts provides some form of explanation for what it was that Münsterites claimed they were creating and promoting with their Anabaptist Kingdom. They further inform us that the design of the Anabaptist Kingdom was not primarily undertaken for Münsterite advantage, but was fully expected to benefit persons living outside the city. According to Münsterite rhetoric, the Anabaptist Kingdom was structured as a socio-political model, and was offered for acceptance to Anabaptist Münster's critical audience. Through the radical social and political changes Anabaptist

11. The writings of Bernhard Rothmann (1495-1535?) are the single largest exception. See Robert Stupperich, ed., Die Schriften der Münsterischen Täufer und ihrer Gegner, vol. 1., Die Schriften Bernhard Rothmanns (Münster: Aschendorff Verlagsbuchhandlung, 1970). Hereafter abbreviated SBR.

12. Carl Adolf Cornelius, ed., Die Geschichtsquellen des Bistums Münster, vol. 2, Heinrich Gresbeck, Berichte der Augenzeugen über das Münsterische Wiedertäuferreich (Münster: Theissing Buchhandlung, 1853). Hereafter abbreviated $B D A$.

13. Heinrich Detmer, ed., Hermann von Kerrsenbroch Anabaptistici Furoris Monasterium Inclitam Westphaliae Metropolim Evertentis Historica Narratio, 2 vols. (Münster: Theissing Buchhandlung, 1899-1900). Hereafter abbreviated AFM. 
Münster displayed, it was spectacle and spectre simultaneously, presenting social situations, political structures, and mores, including the desires and judgments of religious and civil authorities in their most graphic physicality. Primary responsibility in the moral and social order being dramatized was set in relation to other Münsterites, and not generally in relation to those outside, even though their audience was set as the primary beneficiary of the dramatic action being presented.

In his introduction to Anabaptistici Furoris Monasterium, Kerssenbrock claims that Münster's common guild hall (omnium curiarum totius urbis domus est communis) is rightly called a spectando spectaria domus or Schowhus (viewing hall). ${ }^{14} \mathrm{He}$ provides his reader with the explanation that the Schowhus functioned as the primary place for lay socio-political deliberations and the formulation of lay political agendas. ${ }^{15}$ A summons to the Schowhus was always an important matter, according to Johannes Windemoller (Anabaptist Münster alderman and spokesperson for Knipperdolling). ${ }^{16}$ As the "commoners" equivalent of city hall, the Schowhus was the primary meeting place (from a lay perspective) for dealing with matters concerning the common good of the city. It was identified with the exaltation of God's glory (Dei glorium illustrandam), the salvation of city burghers (omnium civium salutem), and the enhancement of personal peace and freedom (pacem libertatemque augendam pertineat). ${ }^{17}$ It was at the Schowhus that popular opinion (vulgi opiniones) was "stitched together" by the labouring classes and then acted on, according to Kerssenbrock. ${ }^{18}$ Münster's Schowhus operated in dramatic competition with the city's official council; it was here that social, religious, and political novelties, including changes to ritual practice, were discussed, investigated, and promoted or dismissed. The Schowhus was the place most intimately associated with the advent of Anabaptists in Münster and their rise to power, in Kerssenbrock's thinking. ${ }^{19}$

14. AFM, 77.

15. $A F M, 77$.

16. AFM, 217.

17. AFM, 213-214.

18. AFM, 77.

19. AFM, 77 and 213. 


\section{Social theatre and Anabaptist Münster}

Münsterite social theatre can be described as a "theatre of disorder" in which the presentation of social "realities" and the exercise of power ranged from the absurd to the vanguard, materially demonstrating Wallace Stevens's statement: "A violent order is disorder." ${ }^{20}$ Münsterite theatre facilitated the imagining of social, political, moral, and religious alternatives through its display, exposure, and dramatic destabilization of the existing order. It constituted a spectacle in which civic leadership was obsessed with its own prestige, power, and political superiority, precluding the thoughtful governance of its citizens. Its display of disorder was an important first step toward the investigation and implementation of radical social change. Turning the sixteenth-century socio-political world upside down and its ideological systems inside out, through the medium of social theatre, was a method for setting them aright once again. It was in dramatizing and self-consciously transgressing the strict boundaries of the existing sociopolitical order-its structure, principles, values, and coercive power-that the Anabaptist Kingdom created an opportunity for imagining new social possibilities and alternative political systems. Therefore, the Anabaptist Kingdom is not best interpreted as a tragedy, debacle, aberration, or disaster designed by fanatics as has frequently been suggested, but as a dramatized display of order and disorder through which an avenue for socio-political change was made available, even if it did not establish a clear timeline or definitive direction for further action.

Despite the large number of beheadings, Münsterites frequently stated that they did not engage in any form of violence that was not widely practised in their contemporary society. Anabaptists were regularly executed in the early modern period for their culturally peculiar practice of baptism and their failure to attend church services, which appear to the modern reader as arbitrary, unjustified, and ill-founded judicial acts. However, capital punishment was deemed necessary in sixteenth-century society when these "harmless" acts were cast as deeply subversive political acts of resistance. Similarly, any form of internal dissention, strife, or political resistance in Anabaptist Münster was speedily and decisively dealt with through executions, with both socio-juridical systems establishing order and averting political danger through violence. Official acts of violence maintained strict boundaries defining and regulating acceptable behaviour.

20. William W. Demastes, Theatre of Chaos: Beyond Absurdism, into Orderly Disorder (Cambridge: Cambridge University Press, 1998), v. 
Many of the sanctified forms of violence practised by the dominant powers were duplicated in Anabaptist Münster. Acts of violence by administrators were justified through religious rhetoric in both cases. Anabaptist Münster proved to be a case of comic tragedy in which the primary caretaker of moral truth was exposed as the worst offender against its own rules, thereby imitating the priorities and actions of an all-too-recognizable violent medieval world.

Münsterite rhetoric to the contrary notwithstanding, Münsterite violence and the meanings ascribed to it cannot be accepted as attenuated just because it mimicked or parodied the violence of the dominant society. Nor can the violence to which sixteenth-century Anabaptists were systematically subjected be understood in isolation, apart from the economic, social, and political structures within which it occurred. ${ }^{21}$ Münsterite violence, like the religiously sanctioned violence of the larger society, was not simply the product of intolerance but an essential mechanism that worked "positively" in the maintenance of certain social, economic, political, moral, and gender biases, obviating the possibility of abrupt or radical socio-political change not initiated by those holding dominant power. In both cases, violence served a regulatory, educational, and mnemonic purpose, eradicating doubt and any attempted contestation of boundaries established by administration. Ritualized violence in Anabaptist Münster could serve a variety of purposes, just as it did in the dominant society, reinforcing the status quo and thereby providing the perception of stability; or, it could introduce radical change within a relatively short period of time. ${ }^{22}$ Radical transitions from a coalition government consisting of guild masters, to a patriciate and prophet, to an elders' constitution, and finally to a theocratic monarchy marked decisive breaks with the earlier form and were made possible through violence, or the threat of violence. Each new order was said to be divinely instituted at the time of its inauguration.

The system of justice and the penal code established by King Jan van Leiden in Anabaptist Münster were generally unencumbered by such things as formal trials, with damning testimony against the accused typically deemed adequate for judgment, especially, it would seem, when the defendant was female and the accuser her husband. ${ }^{23}$ Although the judicial process was pared

21. David Nirenberg, Communities of Violence: Persecution of Minorities in the Middle Ages (Princeton: Princeton University Press, 1996), 11.

22. Nirenberg, 230.

23. See for example, $B D A, 85$. 
down considerably in Anabaptist Münster, the range of offenses for which capital punishment was prescribed was broadened substantially, with cursing a ruler or one's parents, lying, stealing, speaking obscenities, slandering, spitting at one's husband, muttering against one's husband, and insubordination to one's husband all becoming capital crimes. ${ }^{24}$ Wearing old or ragged clothing, like fishing, baking and brewing, was a punishable offence. ${ }^{25}$ King Jan van Leiden and Governor (stathelder) Bernd Knipperdolling acted as judges and shared the office of executioner. Jan van Leiden confessed to personally dispatching fortyeight persons, and Knipperdolling admitted to beheading twelve or thirteen persons. ${ }^{26}$ Leiden and Knipperdolling were part of a juridical-political system that maintained communal unity and ensured compliance with all dictates through the execution of the socially anomalous and politically disruptive, instilling a strong sense of fear into all who remained within the city.

Though heavily symbolic and highly ritualized, Münsterite theatre remained a type of "life event and not a copy of one,"27 to use the terminology of Timothy J. Wiles. It did not present "what might happen," as Aristotle defined drama, but rather "what actually happens," with Münsterite action consisting of the contingent, fragmentary, temporally specific, and unrepeatable activities that have the benefit of being real and not ideal. ${ }^{28}$ As a living theatre, Anabaptist Münster presented what Wiles has described as the "actuality of contingent activity as opposed to the imitativeness of ideal action" through the effective use of theatre's materiality and didactic possibilities. ${ }^{29}$ Unlike "real life" (if a distinction must be made), Münsterite theatre was a socio-political representation that embraced disorder and resistance, embedding and exercising significant power while serving an educational function. ${ }^{30}$ King Jan van Leiden

24. See AFM, 582-86, for a complete list.

25. Richard van Dülmen, ed., Das Täuferreich zu Münster, 1534-1535 (Munich: Deutscher Taschenbuch Verlag 1974), 116. Hereafter abbreviated DTM. See also BDA, 293.

26. $B D A, 373-78$.

27. Timothy J. Wiles, The Theatre Event: Modern Theories of Performance (Chicago and London: University of Chicago Press, 1980), 114.

28. Wiles, 115.

29. Wiles, 116.

30. Martha Ellen Stortz, "Ritual Power, Ritual Authority," in Religious and Social Ritual: Interdisciplinary Explorations, ed. Michael B. Aune and Valerie Marinis (Albany: State University of New York Press, 1996), 122. 
established himself as orator and educator, frequently explaining the benefits of his violent and self-serving actions to his audience. The design and orientation of social theatre are not necessarily or primarily socially conservative. In fact, Münsterite theatre effectively challenged traditional practices and conventional thinking, encouraging resistance and channelling subversion, and thereby proving instrumental in provoking socio-political change even where it did not supply a definite course of action. ${ }^{31}$ The Münsterite choice of social theatre was, therefore, the appropriation of a pre-existing dramatic mechanism (Schowhus) that was extended to encompass the entire city, and was deployed as an eminently suitable tool for the expression of socio-political resistance and the presentation of radical alternatives. Münsterite theatre presented the ordinary person in a variety of roles but always within the grip of abusive power, and, therefore, wholly incapable of transcending present conditions.

\section{Staging the Anabaptist Kingdom}

The appropriation and imaginative exploitation of the Schowhus, and its expansion to the entire city of Münster, including opposing forces outside its walls, provided spectators with an opportunity to "observe" and vicariously participate in the unfolding action even when they did not personally witness the action within the walls. News from persons leaving the city, propaganda pamphlets, city negotiators, and imaginative speculation positioned Anabaptist Münster's audience to gain "theoretical truth," ${ }^{32}$ where direct engagement through sight was not possible. Anabaptist theatre provided its audience with an occasion to participate at various levels in the sociological, political, moral, and religious innovations that it dramatized. The allure of the Anabaptist Kingdom was such that few successfully resisted some form of engagement. During its early months, many Dutch Anabaptists sought to immigrate to the city; during the siege, a significant number of mercenaries from the besieging army defected to the Kingdom, and throughout its existence many tracked developments and

31. Susan Bennett, Theatre Audiences: A Theory of Production and Reception, 2nd ed. (London and New York: Routledge, 1997), 21.

32. Martin Jay, Downcast Eyes: The Denigration of Vision in Twentieth-Century French Thought (Berkeley: University of California Press, 1994), 25. Jay is building on the earlier work of Hans Jonas, "The Nobility of Sight: A Study in the Phenomenology of the Senses," in The Phenomenon of Life: Toward a Philosophical Biology (Chicago: Northwestern University Press, 1982). 
were eager for news. At its demise, most appeared eager to share their thoughts, opinions, criticisms, and evaluations with anyone who would listen. Curiosity, hope for a better life, strong criticism, and open hostility were all forms of engagement with Münsterite theatre.

\section{Interpreting the Anabaptist Kingdom}

While reflecting on the Anabaptist Kingdom shortly after its demise, Corvinus referred to it as an "evil tragedy" that ended not with the execution of Anabaptist Münster's leaders but with the installation of their cages on St. Lambert's tower. ${ }^{33}$ Ironically, the conclusion to the drama could only be realized through the erection of a permanent mnemonic device, which was built a good many months after the city had been retaken by the princebishop's forces, and long after most Münsterite males and all principal players in the Anabaptist Kingdom had been tortured and executed. ${ }^{34}$ Martin Luther described Anabaptist Münster as a "Devil's Play" (Teufelsspiel) that effectively displayed to any and all observers exactly how it is that "the Devil keeps house." ${ }^{35}$ In Caspar Schwenckfeld's assessment, the dramatic action decisively proved that biblical references to the "right and true" Temple could not possibly be held in reference to the material world; Schwenckfeld concluded that all such references must denote a figurative temple. ${ }^{36}$ Friedrich Dürrenmatt stated that typologically only two interpretive possibilities for Anabaptist Münster exist: either Jan van Leiden was a tragic hero, or he was a classic villain. The archetypical range of Dürrenmatt's interpretation is spectacular, encouraging an assessment of the Anabaptist Kingdom in which Jan van Leiden becomes a dramatic representation of everyone who exercises power. ${ }^{37}$

With each social and political transformation, Münster was heralded as a "godly" city, undergoing change in a way that no other German city during the sixteenth century could rival. Reformation in the early modern period

33. Adolf Laube, Annerose Schneider, and Ulmann Weiss, eds., Flugschriften vom Bauernkrieg zum Täuferreich (1526-1536), vol. 2 (Berlin: Akademie Verlag, 1992), 1698-1725. Hereafter abbreviated FBZT.

34. FBZT, 1698-1725.

35. DTM, 286.

36. DTM, 286.

37. DTM, 294. 
simply did not transform urban centres into godly cities as was expected or propagated, ${ }^{38}$ and none underwent the sort of radical physical and social mutations Anabaptist Münster experienced. The Anabaptist "godly city" was profoundly transformed, shaping and reshaping its inhabitants physically, morally, politically, economically, and socially, while deeply imprinting popular imagination throughout the Holy Roman Empire. The Anabaptist Kingdom appeared relatively quickly and disappeared almost as quickly, but it affected socio-political policy for more than a generation throughout much of Europe. The symbolic import it retained and the representational power it displayed, including the myths it propagated and with which it became identified, were effectively embedded in the popular imaginations for generations, while its more colourful aspects continue to be of interest to modern directors, writers, artists, and politicians. ${ }^{39}$ As recently as $1922-23$, when inflation in Germany was extremely high, some of the Notgeld (emergency bank notes) circulating in the city of Münster displayed an image of King Jan van Leiden.

Anabaptist Münster came into being without a "pre-written" script and without a pre-determined, definite end in sight; yet this does not render it an illusion, meaningless, irrelevant, or inconsequential. Rothmann insisted throughout its duration that no one should think of the Anabaptist Kingdom of Münster, which was the manifestation of the Kingdom of God on earth, as a fantasy. ${ }^{40}$ For Münsterites and other sixteenth-century actors, it was a very real world capable of creating fictive worlds in the imaginations of spectators and participants, even if all such constructions were transitory and less than complete. The theatrical quality of Anabaptist Münster was recognized by Münsterites, who frequently described the dramatic action in which they were caught up as the presentation of an example or pattern for community, and as a model of the exercise of power ${ }^{41}$ It was offered for examination, evaluation, and some indefinite form of acceptance and adherence, but not criticism. ${ }^{42}$ Discrepancies, uncertainties, ambiguities, difficulties, and

38. Thomas Brady, "In Search of the Godly City," in The German People and the Reformation, ed. R. Po-chia Hsia, 31.

39. Mennonite Encyclopedia, 3:778.

40. SBR, 276.

41. BDA, 92.

42. Susan Bennett traces the two possibilities offered in theatre (criticism and adherence) to the work of Roland Barthes on Brecht and Eisenstein. Susan Bennett, Theatre Audiences: A Theory of Production and 
unpleasantries, including their affects, were typically offset psychologically within the Anabaptist Kingdom through promises of future understanding and redemption. Münsterites claimed, in one of their propaganda pamphlets, that at an indefinite future time people will point to Anabaptist Münster and say: "See, there is the true Christian community; that is godly authority" ("Seht, dat ist die recht christlich gemeinde, das ist ein gotliche obrigkeit").43 All disagreeable present realities were simply dismissed as passing shadows, temporarily obscuring a better world about to be born.

The restoration of the world, of which Anabaptist Münster was the first fruit, was understood by Bernhard Rothmann and other Münsterites as a material reality involving the physical re-formation and re-construction of the world in all its socio-political nuances and moral aspects. It was a reconstruction of the world that called into question the intrinsic worth of established moral systems, existing social institutions, and expressions of political power, including the conditions under which they developed and were maintained. Münsterites typically rejected outright any suggestion that the restoration to come was to be a spiritual event, or that it was to be "experienced" internally. Rothmann repeatedly insisted on the very physical, essentially corporeal nature of the kingdom that was being established in Münster, at times speaking of it as a third world that was a complete renewal of the old world; ${ }^{44}$ it was to be a world in which all things without exception were

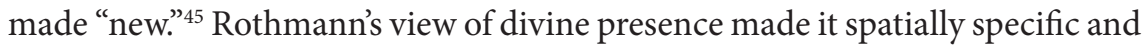
socially transformative-rendering the suggestion that it was spiritual in nature or effect thoroughly inappropriate. Rothmann argued against spiritualized interpretations of Anabaptist Münster, casting them as obstacles to the clear apprehension of truth. His own understanding of the Anabaptist Kingdom as the materialization of scriptural truth rejects the possibility that Anabaptist Münster could be understood rhetorically or allegorically, expressing a strong preference for typological exegesis.

Rothmann further argued that the Anabaptist Kingdom effectively presented the problem of the dual nature of human existence, with the time of

Reception, 2nd ed. (London and New York: Routledge, 1997), 27.

43. SBR, 434. (All translations are mine.)

44. BDA, 365.

45. SBR, 364 and SBR, 393. 
human captivity and the time of redemption reflecting the two worlds in which Münsterites must live concurrently. The existential condition Rothmann's thinking created operated as a single coin with two sides that were to be handled simultaneously until their separation was permanent and complete. ${ }^{46}$ Münsterites frequently drew on biblical language, concepts, and themes when describing their efforts to dramatically reconstruct the world, recognizing at times the very real limitations of their knowledge and ideological resources. The Hebrew Bible provided Münsterite Anabaptists with the historical precedent they sought, and the New Testament provided them with their theological argument, but it was in guild political ideology that they found the language and concepts required for their "millenarian drama." The notion of Anabaptist Münster as a godly tribe appropriated Hebrew Bible history for legitimation, and the adoption of sixteenth-century guild social practice provided rhetorical resonance. ${ }^{47}$ Rothmann acknowledged the epistemological problem attending the interpretation of the Anabaptist Kingdom and argued that examples or pictures (belde) are all that humans have available to them until the "Restoration" is complete. With the "Restoration," understanding will become full, but until then, he insisted, humans have no option but to deal with "dark riddles" (raitzelen), and are forced to look for truth in the reflections offered by a mirror. ${ }^{48}$ As one such mirror, the Anabaptist Kingdom dramatized the dark riddle surrounding the assumption of divinely sanctioned power within the community, bringing into the audience's view the casualties such an authorization generates.

Anabaptist Münster's fluctuation, between the presentation of all that was to be avoided in the exercise of power and its portrayal of a socio-political model that was to be imitated and broadly emulated, reflected the moral, social, and political commitments of its sixteenth-century viewer. The examples it provided and the performances of its principal actors were adequately varied and sufficiently ambiguous to permit a wide range of interpretive possibilities. Responses to the dramatic action exposed the values, character, and proclivities of a given audience or audience member every bit as much as it revealed those

46. SBR, 281.

47. R. Po-chia Hsia, "Münster and the Anabaptists," in The German People and the Reformation, ed. R. Po-chia Hsia, 64, 69.

48. SBR, 335-36. 
of a Münsterite actor. Münsterites held that the precise "meaning" attached to the Anabaptist Kingdom and the action it presented were always a function of time, and left the matter open to individual interpretation. However, the need to interpret the dramatic action was never optional. The action was presented as "truth," and this "truth" required a definitive response.

Heinrich Dorpius recognized the dramaturgical nature of Anabaptist Münster and accepted its didactic possibilities, but he also noted that things did not develop in Anabaptist Münster the way Münsterites imagined (getreumet) they would, which created a substantial disjuncture. ${ }^{49}$ Dorpius assumed a deterministic attitude in his assessment, arguing that things in Münster developed as they always must in such cases. ${ }^{50} \mathrm{He}$ implied that a certain type of logic governs socio-political affairs, dooming the Anabaptist Kingdom from the very start. Dorpius encouraged his reader to "see" the Münsterites and their kingdom, not as an example to follow, as Münsterites propagated, but as an example to be avoided. ${ }^{51}$ Anabaptist Münster, in Dorpius's thinking, effectively provedwhether Münsterites intended it that way or not, and regardless of whether or not they acknowledged it-that certain moral values (or their absence) as well as some socio-political structures and policies are simply not to be implemented or universalized. Nor are they to be explored, transmitted, transplanted, or reconstructed in some form elsewhere. The replication of Anabaptist Münster in any form, facet, or manner was to be avoided at all costs, ${ }^{52}$ according to Dorpius, as it violated some sort of primary logic written into the universe governing human affairs. For many, Anabaptist Münster's primary didactic value rested in its ability to function as a clear and unmistakable warning to others.

\section{Spatial practices in the Anabaptist Kingdom}

Münsterites renamed city gates and streets to reflect their new identity, and a policy was established whereby the king named all newborn children. The renaming of streets, lanes, and gates developed a spatial understanding that inaugurated a new political and social order, engendering a new power structure that superseded the old order. Small boards with new street names were hung

49. FBZT, 1681.

50. FBZT, 1681.

51. FBZT, 1681.

52. FBZT, 1681. 
in lanes, and letters containing a simple rhyme were attached to city gates, advertising their new names in a quickly identified and easily remembered format. ${ }^{53}$ Fences demarcating private property and establishing boundaries were torn down, and all entrance doors to residences were left unlocked, regardless of whether it was day or night. ${ }^{54}$ Public space, and not merely public access, was substantially enlarged through these innovations, presenting new rhythms and consequently new opportunities and challenges into everyday life. The peculiarities of a given place, the exclusive rights of occupancy, and hitherto private spatial practices were substantially challenged through the introduction of a new level of transparency. No other early modern German city underwent a spatial transformation that can rival Anabaptist Münster's.

Innovative spatial practices in the Anabaptist Kingdom included the commissioning of five or six new schools with fresh curricula. ${ }^{5}$ During Pentecost, 25 May 1534, Münster's city hall and roof were repurposed as a simple storage facility for confiscated scaling ladders. ${ }^{56}$ Many living spaces were traded, with some who had been living in the city relocated outside city walls, and strangers to the city were often given homes within city walls. ${ }^{57}$ Clerical quarters were "renovated" into residences for "immigrants," 58 and monasteries were repurposed as prisons and barracks. ${ }^{59}$ Churches, chapels, the cathedral, and the cathedral square were all renamed with many assuming altogether novel functions. The Rosenthal convent, for example, became a prison for "quarrelsome" women who refused to be married, and for recalcitrant wives who refused to obey their husbands. Each of the churches was given a new name employing some variant of stone pit (steinkule), and punishment was meted out to any Münsterite caught using the former name of a gate, street, or church. ${ }^{60}$ The marketplace and cathedral square were established as the primary place for preaching, public assembly, and the dissemination of information, decisively

53. BDA, 154 .

54. BDA, 47.

55. BDA, 47.

56. BDA, 52.

57. BDA, 97.

58. AFM, 541-42.

59. BDA, 65, and 165 .

60. BDA, 158. 
displacing the medieval church. The cathedral square was renamed Mount Zion (bergh Sion) and was established as the primary site for the working of righteousness, the implementation of order, and the dispensing of justice in the form of executions. ${ }^{61}$ It was the only former church property that was given a new name holding positive connotations in Anabaptist Münster. Through Anabaptist initiatives, the city was transformed from a place of fine houses, trees, gardens, fences, large monasteries, and elegant churches into a fortress that redefined its power and wealth. ${ }^{62}$ These spatial changes transformed Münster visually, and substantially revised daily life, radicalizing Münsterite representations of the world while transforming Münsterites through their reorganization.

It was through the initiative of Anabaptist Münster's "preachers and prophets," according to Gresbeck, that language describing Anabaptist Münster as a new creation and model for the rest of the world was developed and popularized, ${ }^{63}$ but it was through Münsterite action that the city of Münster became a very different sort of place. The Anabaptist Kingdom was the New Jerusalem, with all former church identities and associations necessarily displaced. A more desirable quality of life was inextricably linked to a socio-political place that required construction. The language developed by Anabaptist Münster's "preachers and prophets" defined "true religion" as a spatial innovation that was closely tied to moral, economic, psychological, and social improvements, with Gresbeck cautiously accepting the argument that "true religion" always has the effect of providing a better or a good life (das Leben gebessert). ${ }^{64}$ The socially, economically, politically, and morally superior life that Münsterites desired and claimed to be dramatizing was intimately tied to their reconstruction of the city, even if contemporaries such as Gresbeck and Kerssenbrock saw little beyond disorder, foolishness, and destruction, and openly rejected Münsterite descriptions and self-referential claims. The radical policies, procedures, and orders Münsterites designed and implemented often appeared to be in substance and effect, as Gresbeck and Kerssenbrock were quick to point out, the exact opposite of what Münsterites claimed to be creating. ${ }^{65}$

61. BDA, 121.

62. $B D A, 177$.

63. BDA, 92.

64. $B D A, 162$.

65. See for example, $B D A, 94$. 
Gresbeck was quick to dismiss the existential claims of Münsterites, but he readily acknowledged that the preachers and prophets of Anabaptist Münster were rather adept at keeping Münsterites bound up in the folly they collectively presented, implying that they were very good actors. ${ }^{66}$ Kerssenbrock, on the other hand, complained that leading Münsterites were not playing "real parts"; they were participating in a production that lacked seriousness, presenting nothing beyond deception and the crudest forms of foolishness. Kerssenbrock complained that it was not enough for the "foolish and stupid" Münsterites to have a "theatre-king" (scenicum regem) and "whore-guardian" (scortorum praesidem) in Jan van Leiden, but they also insisted on retaining a good many "theatre-courtesans" (scenicas meretrices). ${ }^{67}$ It was with good reason, according to Gresbeck and Kerssenbrock, that persuasive Münsterite preachers were chosen as the Anabaptist Kingdom's apostles and foremost ambassadors by Jan van Leiden. They had proven themselves highly influential and effective in comanipulating Münsterites through their dramatic prowess, making it reasonable to assume that they would also be successful in manipulating persons outside the city walls in their campaign to solicit help against the bishop's forces. ${ }^{68}$

The spatially specific discourse of truth that was produced, propagated, and put on display in Anabaptist Münster was shaped and mediated by Münsterite understandings of current social, economic, moral, and political exigencies, and not primarily by their condition as a besieged city. As difficult as the siege made life in the Anabaptist Kingdom, it was always organized by the controlling ideology of place Münsterites adopted, through which multiple forms of action, reaction, and constraint were introduced. ${ }^{69}$ At various times, formal opportunities were extended for the discontent to leave Anabaptist Münster. Those who accepted what appeared to be a magnanimous offer were then derided, abused, and dismissed from the city as faithless, godless, and entirely unworthy persons. Leaving the city without permission was a capital offence, with the intent to leave considered synonymous with desertion. When the intent to leave was discovered, these "deserters" were summarily executed

66. BDA, 136.

67. AFM, 656-57.

68. BDA, 111-12; and FBZT, 1630 and 1678.

69. Michel Foucault, Power/ Knowledge: Selected Interviews and Other Writings 1972-1977, ed. Colin Gordon, trans. Colin Gordon, Leo Marshall, John Mepham, and Kate Soper (New York: Pantheon Books, 1980), 131. 
by Münsterite leaders. ${ }^{70}$ Women and children who wished to leave Anabaptist Münster were permitted to do so on a few occasions, but only after they were stripped of their clothes and dressed in older ones. ${ }^{71}$ The potentially redemptive understanding of place that Anabaptist Münster developed-including its relative value, its meaning for the individual, and its relation to the divineseparated humanity into two very distinct and socially determinative groups: the godly and the godless. The godly were assumed to hold unlimited promise despite their present difficulties by virtue of their privileged dwelling place, and the godless were bereft of all hope for the future given the place they occupied.

Such a polarized assignment of spatial values was predicated on a fundamental re-description of the world in which natural forces and the current socio-political world were simply regarded as surreal. The world Münsterite action produced, on the other hand, was neither fictional nor imaginary but a place considered more "real" than the phenomenal world, as it came into existence as the product of a divinely inspired imagination. Anabaptist Münster was, in its effects, a powerful social theatre that designed and developed an environment effective for exploring radical social change through the fictional worlds that were created in the imaginations of spectators and participants. ${ }^{72}$ In Rothmann's words, Münster was established as the primary place for the refreshment (erwickinge) and deliverance (erloezynge) of "true" Israelites, with emphasis placed on the separation and escape of Münsterites from the oppressive and tyrannical controlling forces of "Babylon." ${ }^{33}$ It was a world in and through which a good many impossibilities became possible through spatial transformation.

\section{Münsterite theatre: myth, deception, and play}

Distinctions between empirical reality and the dramatic reality Münsterite theatre presented were not always well understood, strictly enforced, rigidly observed, or carefully articulated. But Gresbeck, like others in the city, claimed

70. BDA, 24, 28-30, 33, 125-27, 172, and 189.

71. FBZT, 1648.

72. Eli Rozik, Generating Theatre Meaning: A Theory and Methodology of Performance Analysis (Brighton and Portland: Sussex Academic Press, 2008), 85.

73. SBR, 340. 
to possess a keen vision that penetrated an understanding of what exactly was being displayed in the Anabaptist Kingdom. He claimed to see that the ethical self-formation being encouraged was a preoccupation with self-abnegation and unreserved submission to a veiled form of primary evil. Compliant responses were a form of subordination that authorized the widest possible range of action. The claim to see through the chimera being presented to what lay behind dramatic events does not negate the skill of Jan van Leiden in destabilizing and then maintaining Münsterites within an uncertain and disorienting environment in which they became absolutely dependent. Despite his claim to see through the drama being presented, an assertion through which Gresbeck could claim to have maintained a profound form of independence, like so many others in Anabaptist Münster, he knowingly offered his assistance to the Münsterite regime, becoming complicit in the deception it generated and the power it exercised. ${ }^{74}$ The support these "knowing" individuals provided does not necessarily prove uncritical collaboration, but it does demonstrate the effectiveness with which Anabaptist theatre operated.

Heinrich Graes, like Gresbeck, offered his assistance to Anabaptist Münster in a leadership capacity for a period of time. Writing to fellow Münsterites after his defection to the camp of Franz Waldeck, prince-bishop of Münster, Graes declared the Anabaptist Kingdom to be a false and poisonous business (falsch und vergiftet Handel) that imploded (eingebrockt ist). ${ }^{75} \mathrm{He}$ offered his correspondents insight and understanding, claiming that the whole thing was nothing more than a series of reflections in a mirror that have proven to be a piece of cheating (alles Betrug ist). From the enemy camp, Graes begged Münsterites to “open their eyes" even as he recently had opened his, encouraging them to adopt a very different position vis-à-vis the drama in which they were participating. Penetrating vision was required to see the Anabaptist Kingdom for what it truly was, ${ }^{76}$ while conceding that Anabaptist Münster had effectively enveloped not only those inside but also those outside the city in its theatrical deception. ${ }^{77}$ Unlike Gresbeck (who claimed that many knew the truth), Graes claimed he was one of a limited number of individuals who knew the truth

74. Gresbeck rationalizes his complicity as a self-preserving necessity. BDA, 94 and 92.

75. DTM, 223.

76. BDA, 296; and DTM, 223.

77. DTM, 223. 
about Anabaptist Münster, remaining convinced, even after his defection, that the power Anabaptist Münster exercised was effectively concealed, and not only effectively exercised.

\section{The destruction of Münster's churches}

Most sixteenth-century Anabaptists shunned the established church and tended to denigrate it in their conversations, confessions, and writings, but acts of iconoclasm and violence against church buildings were relatively sporadic, geographically isolated, and generally limited in their destructive scope. Hanns Grembser admitted to thoughtlessly kicking (unbedachten muett gestosssen) an image until it broke; ${ }^{78}$ on 11 July 1533, Vinzenz Puchl admitted to intentionally breaking a crucifix $;^{79}$ in 1529 , a group of five men vandalized an image of the Virgin Mary by hacking her face. ${ }^{80}$ Anabaptist violence against churches set a new benchmark in the early weeks of the Anabaptist Kingdom and included the desecration of Münster's cathedral, ${ }^{81}$ the burning of St. Maurice, the forcible removal of clergy and service items, and the wholesale plundering of church interiors. In later months, most church towers, roofs, walls, and interiors were destroyed. In the case of St. Jacobus, instructions were specifically issued that no part of the church was to remain standing higher than the stature of a man..$^{82}$ Divine prophecy informed Anabaptist Münster's prophets and preachers as they announced the imminent destruction of the city's churches and monasteries, with the impending destruction interpreted as divine action against these places as a result of the wrath they had drawn to themselves. ${ }^{83}$ Through the radical spatial transformation of the city, Anabaptist Münster became qualitatively unique in early modern Germany.

During his interrogation, Bernd Knipperdolling denied personally advising the destruction of Münster's churches, but he did admit to assisting in

78. QZGWT/QZGT/QZGT Schweiz. Quellen zur Geschichte der Widertäufer/ Täufer, 20 vols. QZGT, Osterreich, 3:137.

79. QZGT, Osterreich, 3:136.

80. Their names were Andre Planer, Walthasar Huter, Cristen Müllner, Caspar Swartz, and Peter Kober. QZGT, Osterreich, 2:238.

81. BDA, 18. BDA, Chronik des Schwesterhasuses Marienthal, Genannt Niesinck in Münster, 431.

82. BDA, 187.

83. BDA, 13-14. 
their devastation, arguing that their annihilation was necessary because "God was only to be honoured in the living temple and hearts of people" ("Got allein in dem levendigen temple und hertzen der menschen geert werden"). ${ }^{84} \mathrm{He}$ stated that the dwelling place God wanted to erect through Anabaptist Münster was to eclipse the beauty and glory of Solomon's temple, with Münster's current church buildings operating as an obstacle to the realization of such a goal. Gresbeck draws his reader's attention to the dramatic irony created when the predicted divine destruction of church buildings in Anabaptist Münster did not materialize, ${ }^{85}$ but that these same buildings fell through human initiative and action. ${ }^{86}$

During his confession of October 1534, the former Münsterite pastor Dionysius Vinne of Diest referred to the cathedrals and churches in Münster as death-pits (moirtkulen) and temples of Baal (Baals tempelen) ${ }^{87}$ Both terms were common Anabaptist descriptors for medieval churches and linked these places with moral compromise, physical destruction, and social devastation. Because Münsterites associated church buildings with a specific ideological system and the maintenance of a particular social structure, it stands to reason that these same buildings would have to be destroyed or substantially altered to make room for a competing ideology and a new socio-political structure. Moreover, it is not altogether surprising that the first churches to be attacked in Anabaptist Münster were the cathedral, the former cathedral, and their attendant chapels (with the exception of St. Jacobus), given that they most clearly represented the bishop of Münster and the interests of the wealthy. ${ }^{88}$ The bishop's coat of arms was dramatically ripped off the cathedral wall and trampled in feces.

When Münsterites attacked church interiors they typically destroyed the monstrance, images, and vessels these places held, assaulting the exclusive hold the medieval church exercised over salvation and the holy. Those stained glass windows on which they found an ancestral coat of arms, images of saints, or

84. BDA, 408-09. Heinrich Dorpius's pamphlet of 1536 contradicts Knipperdolling's testimony. It states that Knipperdolling publicly announced in April 1534, about 4-5 days after Easter, that all that is high was to be brought low and that which is low was to be made high. Knipperdolling instructed fellow Münsterites to destroy the monasteries and churches just as the Father had revealed it to him. FBZT, 1674.

85. BDA, 18.

86. BDA, 14.

87. BDA, 274.

88. BDA, 159 . 
representations of God the Father or Jesus Christ were smashed with sticks and clubs. However, depictions of the devil, Jews, and the godless were often left undamaged. ${ }^{89}$ These traditional representations of "evil" were allowed to remain relatively intact and were often completely untouched, but traditional representations of divinity, saints, and the pious, whether in the form of pictures, drawings, images or paintings, which functioned as encouragements to veneration, were ruthlessly attacked. The explanation tendered by Anabaptist leaders for the devastation of church interiors claimed that their destruction obviated the possibility of their being used to influence Münsterite youth in the future..$^{90}$ Many of the large stones from the ruined churches, including their large altar stones, were repurposed as fortifications in the foundations of dirthouses (erthueser) constructed in front of the city gates, and others were used to patch gates that had holes shot through them. ${ }^{91}$ These formerly sacred stones were reduced to raw building materials to be exploited as required, and were fundamentally divorced from any symbolic or sacred values they once held. Some churches were totally and utterly destroyed and/or dismantled, including their exterior walls, through a pragmatic reassignment of their value and function..$^{92}$ Gresbeck claims that it was the intention of Münster Anabaptists not only to destroy these church buildings but to deal similarly with churches outside the city walls, when Münsterites proved politically and numerically strong enough to be able to do so, even if there was no obvious or immediate need for additional raw building materials.

\section{Conclusion}

What Münsterites claimed was a model of truth regarding the exercise of power was the dramatic presentation of what Bruce Lincoln has termed "paradigmatic truth." ${ }^{93}$ The destruction of Münster's churches, and the willingness of Münsterites to fight to the last person in defence of their holy city, indicate that establishing

89. DTM, 90.

90. DTM, 91.

91. BDA, 162.

92. BDA, 161 .

93. Bruce Lincoln, Discourse and the Construction of Society: Comparative Studies of Myth, Ritual, and Classification (New York and Oxford: Oxford University Press, 1989), 24. 
and maintaining a place sixteenth-century Anabaptists could call their own, and which they could shape to their liking, was of primary and not secondary importance. For Münsterites, the city was a possession of ultimate value-but like any other commodity, they demonstrated that it could be squandered, abused, won, or lost. Their experimentation with social structure and their dramatization of the exercise of power were always accomplished through the construction of a particular type of place, which was always intimately and inextricably tied to specific meanings, values, and existential realities. In Knipperdolling's last recorded reflections, he conceded that the redemption Münsterites actively sought through their construction of a holy city was misdirected and misplaced. He asserted that deliverance, if obtainable, is only available internally or spiritually, declaring the possibility of physical deliverance from adverse, absurd, and violent circumstances entirely impossible. ${ }^{94}$

Although the myths surrounding the election of Münsterites and their holy city identified and mobilized a particular social grouping, acting as the impetus and platform for their investigation of an alternative form for society, it was through the physicality of the drama they presented that "truth" was more perfectly apprehended. The godly Anabaptist city was not successful by most standards that have been applied to it. However, as a discursive act, the Anabaptist Kingdom of Münster constituted a disordered space effective in the dramatization of the exercise of power, proving conducive to the investigation of the manner and mechanisms by which power is exercised. Anabaptist Münster proved to be eminently suitable for the presentation of power's casualties even if its members were unsuccessful in their attempts to escape or alter its effects. The Anabaptist Kingdom was a place from which their contemporaries could profit and subsequent generations might learn, and out of which future polities and communities could be shaped and re-constructed, which is exactly what Münsterites said they intended from the very beginning. 